\title{
Evaluation of the immunotoxicological effects of Dimorphandra mollis Benth., Fabaceae, in rats
}

\author{
Cássia A. O. Feres, ${ }^{1}$ Vicente P. C. P. Toledo, ${ }^{1}$ Carlos A. Tagliati, ${ }^{1}$ Josiane B. Piedade, ${ }^{1}$ \\ Fernanda Hermont, ${ }^{1}$ Orivaldo A. A. Rocha, ${ }^{2}$ Tania M. P. D. Guimarães ${ }^{*}, 1$
}

\begin{abstract}
${ }^{1}$ Departamento de Análises Clínicas e Toxicológicas, Faculdade de Farmácia da Universidade Federal de Minas Gerais, Av. Antônio Carlos, 6.627, Campus Pampulha, 31270-910 Belo Horizonte-MG, Brasil,

${ }^{2}$ Departamento de Patologia Geral do Instituto de Ciências Biológicas, Universidade Federal de Minas Gerais, Av. Antônio Carlos, 6.627, Campus Pampulha, 31270-910 Belo Horizonte-MG, Brasil.
\end{abstract}

\begin{abstract}
RESUMO: "Avaliação dos efetos imunotoxicológicos de Dimorphandra mollis Benth., Fabaceae, em ratos". A Dimorphandra mollis Benth., Fabaceae, conhecida como faveira ou favad'anta, é uma planta comum do cerrado central do Brasil, muito utilizada por suas propriedades antioxidante, antiplaquetária e, principalmente, como vasoprotetora. Seu principal marcador é a rutina. Este estudo teve como objetivo avaliar a segurança da utilização do extrato seco de $D$. mollis em roedores. $\mathrm{O}$ extrato foi extraído, padronizado e quantificado apresentando teor de $76,0 \pm 3 \%$ de rutina. Nos parâmetros bioquímicos e hematológicos avaliados, não se observou alterações nos grupos de machos e fêmeas que receberam a dose de 1000 e $2000 \mathrm{mg} / \mathrm{kg}$ de $D$. mollis, mas observou-se um aumento de eosinófilos. Nos estudos histopatológicos detectou-se hiperreatividade da polpa branca esplênica, no grupo que recebeu a dose de $2000 \mathrm{mg} / \mathrm{kg}$ de $D$. mollis. Na avaliação da resposta linfoproliferativa, com 1000 e $2000 \mathrm{mg} / \mathrm{kg}$ não foram observadas alterações, e somente nos estudos com a dose de $2000 \mathrm{mg} / \mathrm{kg}$ se observou diminuição de IgG. Os resultados obtidos, utilizando roedores, sugerem que nenhuma toxicidade existe na administração de extrato seco de D. mollis na dose de $1000 \mathrm{mg} / \mathrm{kg}$.
\end{abstract}

Unitermos: Dimorphandra mollis, rutina, imunotoxicologia, roedores.

\begin{abstract}
Dimorphandra mollis Benth., Fabaceae, also known as "faveira" or "fava-d'anta", is a plant common to the central woodsy meadow region of Brazil. It is well known for its antioxidant, antiplatelet and, principally, vasoprotective properties. Its principal component is rutin. The objective of this study is the evaluation of the safety of the use of the dried D. mollis extract in rodents. The rutin content of the standardized extract was $76.0 \pm 3 \%$. With respect to the biochemical and hematological parameters evaluated, no alterations in the groups of rats that received 1000 and $2000 \mathrm{mg} / \mathrm{kg}$ doses of $D$. mollis were observed, but an increase in eosinophiles occurred. Hyperactivity of the white splenic pulp was detected in the group that received the $2000 \mathrm{mg} / \mathrm{kg}$ dose of $D$. mollis. In the evaluation of the lymphproliferative response with 1000 and $2000 \mathrm{mg} / \mathrm{kg}$, no alterations were observed, and a decrease in IgG was only observed in the studies with a 2000 $\mathrm{mg} / \mathrm{kg}$ dose. The results obtained with rodents suggest that no toxicity exists with the administration of dried D. mollis extract in a $1000 \mathrm{mg} / \mathrm{kg}$ dose.
\end{abstract}

Keywords: Dimorphandra mollis, rutin, immunotoxicology, rodents.

\section{INTRODUCTION}

According to the World Health Organization (2003), $80 \%$ of the world population uses medicinal plants or their sub products for basic health problems. And Brazil is one of the countries with the greatest biodiversity in the world and is an important source of medicinal plants.

Dimorphandra mollis Benth. is a species of medicinal plant known as "faveira"or "fava-d'anta" that belongs to the Fabaceae family. It is common to the central woodsy meadow region of Brazil. The fruits are rich in rutin, a glucoside flavonoid employed in popular medicine. Its principal indication is as a vasoprotector because it causes an increase in capillary resistance by inhibiting hyaluronidase, thereby preventing exudates and transudates to the adjacent tissue and decreases the capillary permeability. It may have potential use in the prevention of pathological vascular states (Da Silva et al., 
2002; Erlund et al., 2000; Hasumura et al., 2004; Janbaz et al., 2002; Nakamura et al., 2000). Rutin also presents antioxidant (Da Silva et al., 2002; Guardia et al., 2001; Hou et al., 2004; Janbaz et al., 2002; La Casa et al., 2000; Schwedhel et al., 2003), as well as exhibiting antiinflammatory (Guardia et al., 2001; Janbaz et al., 2002), antiviral (Janbaz et al., 2002), antitumoral (Janbaz et al., 2002; Shimol et al., 2003), antialergic (Janbaz et al., 2002) and antiplatelet (Janbaz et al., 2002; Sheu et al., 2004; Shimol et al., 2003) activities.

The dried, semi-purified D. mollis extract (DMDE) was considered to be non-classified in the preclinical studies of toxicity, according to the European Community, and presented no toxicity in the pharmacological screening (Féres et al., 2006). However, the DMDE has not been extensively studied, although it is known that it is effective in clinical processes and is not toxic.

Studies related to the immunotoxicity of DMDE, especially its effects on cell proliferation and antibody production have not yet been investigated. The immunotoxicity tests have been accepted worldwide, in view of the fact that the immune system has shown itself to be very susceptible to xenobiotics and any effect that may affect the homeostasis of the immune system is considered to be immunotoxic (Descotes, 2000; Holsapple et al., 2003). This susceptibility to xenobiotics can result in direct immunosuppression or immunostimulation. Although no model exists to assay all immune-mediated adverse reactions for different drugs, animal models might contribute as in vivo screening tools for evaluating the danger of a drug to induce various immunotoxicity results (Nierkens \& Pieters, 2005).

Various studies have shown that natural products are lacking of toxicity and that severe consequences can occur, making it necessary to submit them to tests for efficacy and safety (Bast et al., 2002). In view of these results, worldwide regulatory organs such as the Food and Drug Administration, require proof of quality of products through studies of pre-clinical pharmacological and toxicological activities and clinical assays, in addition to rigorous control of the quality of production, for a pharmaceutical product to be approved and liberated for the consumer market (Ladics et al., 1995).

The objective of the present study was the evaluation of potential immunotoxicological effects of DMDE through functional assays such as the lymphproliferative response, antibody production, protein and globulin levels and histological evaluation of the spleen so as to furnish scientific subsidies for its safe use.

\section{MATERIALS AND METHODS}

\section{Preparation of DMDE}

DMDE was prepared from the fruits of Dimorphandra mollis Benth., Fabaceae, collected in

February, 2003, in the woodsy meadow region in the north of the state of Minas Gerais, Brasil. Botanical investigation was performed after herborization of the material and morphological comparison to exsiccate stored in the SATCETEC (HX-BH) herbarium. The DMDE development was performed by Planta Medicinal Indústria e Comércio Ltda. After collection of the plant material, the samples were dried at room temperature, ground into powder in knife mills, and submitted to extraction with a mixture of hydro-alcoholic solvents. The concentration of the liquid extract was performed to obtain the dried extract, which had the form of an amorphous, yellow powder. Flavonoid determination in DMDE was performed in triplicate by high performance liquid chromatography (HPLC) using the external standard method (rutin). A reverse phase column RP-18 was employed, with gradient elution by a mixture of solvents, at a temperature of $40{ }^{\circ} \mathrm{C}$, flow rate of $1,0 \mathrm{~mL} /$ min and UV detection. This extract was standardized to $76 \%$ rutin.

The experimental suspension was prepared daily by dissolving $20 \%$ DMDE and $0.05 \%$ carboxymethylcellulose (CMC, suspending agent) in $79.95 \%$ distilled water. For the control group, a suspension containing $0.05 \%$ CMC and $99.95 \%$ of purified water was used.

\section{Animals}

Eight-week-old female Wistar rats $(200 \pm 20$ g) were furnished by the bioterium of the Faculdade de Farmácia of the Universidade Federal de Minas Gerais. The animals were kept in cabinets for five days before the experiment, to allow acclimatization and from then on, under controlled conditions of temperature $\left(25 \pm 2{ }^{\circ} \mathrm{C}\right)$, humidity (50-60\%) and $12 \mathrm{~h}$ light/darkness (7:00-19:00 h). The animals were fed with food in pellets and water ad libidum, exception for overnight before each experiment and $4 \mathrm{~h}$ after the administration of the drugs, although they continued to have free access to water. The experimental protocols were approved by the Ethics Committee on Animal Experimentation (CETEA) of the UFMG (protocol $\left.n^{\circ} 17 / 2003\right)$.

\section{Membrane antigen from sheep red blood cells (SRBC)}

The SRBC antigen were determined by the method described by Temple et al., 1993; Van Loveren et al.,1991.

\section{Protein determination}

The protein concentrations of the SRBC antigen and the DMDE suspension were determined by the method described by Lowry et al. (1951).

\section{Immunization of the animals}


The rats were immunized intraperitoneally (i.p.) with 2x 106 SRBC on days 1, 3, 5, 15, 18 and 20. Three days prior to sacrificing the animals, a reinforcement dose of $50 \mu \mathrm{g} / 500 \mu \mathrm{L}$ of SRBC soluble antigen was administered intravenously (i.v.) (Ladics et al., 1995; Temple et al., 1993; Van Loveren et al., 1991). The oral administration (p.o.) of DMDE or the control by gavages was performed daily during thirty days. The rats were divided into six groups of five animals. Group 1: animals treated with the control solution, CMC, via p.o.; Group 2: animals treated with DMDE, $1000 \mathrm{mg} / \mathrm{kg}$ dose, via p.o.; Group 3: animals treated with DMDE, $2000 \mathrm{mg} / \mathrm{kg}$ dose, via p.o; Group 4: animals treated with the control solution, CMC, via p.o., and immunized via i.p. with SRBC); Group 5: animals treated with a $1000 \mathrm{mg} / \mathrm{kg}$ dose DMDE, via p.o. and immunized via i.p. with SRBC; Group 6: animals treated with a $2000 \mathrm{mg} / \mathrm{kg}$ dose of DMDE, via p.o., and immunized via i.p. with SRBC.

After thirty days, serum samples from these animals were collected, and the animals were sacrificed by decapitation. After aseptic removal, each spleen was evaluated macroscopically, and approximately one-third of each spleen was separated for histological studies. The remaining two-thirds were used for obtaining the mononuclear cells used in the lymphproliferative response trial.

\section{Clinical laboratory evaluation}

Biochemical analyses were performed on the animals' serum utilizing Kits Analisa and a Biotron spectrophotometer. Total protein, albumin and globulin were determined. The hematological parameters - number of erythrocytes, leukocytes, hemoglobin concentration and hematocrit - were measured on a Device ABC Vet. The differential leukocytes count was also performed.

\section{Pathological evaluations}

Representative samples of the spleens were collected from the rats. No histological evaluation was performed on the thymus because the evaluation would have to be very carefully interpreted because of the inherent variability associated with its removal, the majority of the thymuses being partially or totally destroyed during the decapitation. All spleens were fixed in 10\% neutral buffered formalin. Processed tissues were embedded in paraffin, cut at a thickness of $5 \mathrm{~mm}$ and stained with haematoxylin and eosin. Tissues collected from rats in all groups were processed to slides and examined microscopically.

\section{Preparation of cell suspension}

A single cell suspension was prepared from each 2/3 spleen in RPMI 1640 (Gibco, Germany). After aseptic removal of the spleens, they were ground and the mononuclear cells were filtered through sterile nylon. The cells were washed with Fazekas St Groth saline solution at $1400 \mathrm{rpm}$ during $10 \mathrm{~min}$ at $18{ }^{\circ} \mathrm{C}$. The erythrocytes were lysed with ammonium chloride solution, and the cells were washed three times with RPMI 1640 and resuspended in the same medium supplemented with $5 \%$ heat-inactivated fetal calf serum, penicillin $(100 \mathrm{UI} / \mathrm{mL})$ and streptomycin $(50 \mathrm{pg} / \mathrm{mL})$.

\section{Lymphproliferative response}

Cells were cultured in triplicate at a density of $2 \mathrm{x}$ 105 cells/well in a 96 well flat-bottomed microplate at 37 ${ }^{\circ} \mathrm{C}$ in a humidified $5 \% \mathrm{CO}_{2}$ atmosphere for five days, with or without DMDE. The DMDE concentration was $35 \mu \mathrm{g} /$ $\mathrm{mL}$ and that of concanavalin A (Con A, Sigma, St. Louis, MO) was $4 \mu \mathrm{g} / \mathrm{mL}$. After incubating for $72 \mathrm{~h}$, cultures were pulsed with $1 \mu \mathrm{Ci}$ of tritiated thymidine per well. Eighteen hours later, cells were collected onto filter mats using an automated cell harvester, and the incorporation of tritiated thymidine into the cells was measured by a liquid scintillation counter (Tricarb 2100, USA). The results were expressed as the mean of three determinations minus the background using cells incubated with RPMI 1640supplemented medium (Alvarez et al., 2004; Benencia et al., 2000; Peijie et al., 2003; Tulinska et al., 2000).

\section{Elisa measurement of the IgG response to SRBC}

The ELISA reaction was performed in polystyrene microplates (Hemobag) sensibilized with $2 \mu \mathrm{g} / 100 \mu \mathrm{L} /$ well of the antigen preparation (SRBC). After developing, the absorbancies were read at $492 \mathrm{~nm}$ with an automatic reader for microplates (Arriba et al., 2002; Ladics et al., 1995; Temple et al., 1993; Van Loveren et al., 1991).

\section{Statistical analyses}

The statistical analysis was achieved with a parametric test for analysis of variance, followed by the Duncan test using the SAEG program. The level of significance used was 5\%. Mathematical adjustments were applied to some parameters to make the variable a parametric response. A Kruskal-Wallis non-parametric test was applied for the analysis of results that did not present a normal distribution and that could not be parametricized.

\section{RESULTS}

\section{Biochemical and hematological analyses}

No significant difference $(p>0.05)$ was observed between the control groups and those treated with the two doses of DMDE or the animals immunized with SRBC in the evaluation of serum proteins (total proteins, albumins and globulins) (Figure 1). Among the hematological 
parameters (Figure 2), those values encountered for erythrocytes, hemoglobin, hematocrit and overall total leukocytes in the rats that received DMDE and/or SRBC are similar to those obtained for the control group $(p>0.05)$. When the differential leukocytes count was analyzed, an increase in the number of eosinophiles was observed when a $2000 \mathrm{mg} / \mathrm{kg}$ dose of DMDE was used, including the association of DMDE with SRBC. No alteration in the percentages of the other leukocytes occurred.

\section{Production of antibodies}

No difference between the levels of $\mathrm{IgG}$ antiSRBC (Figure 3) $(p>0.05)$ in the control groups and the group that received a $1000 \mathrm{mg} / \mathrm{kg}$ dose of DMDE was observed. The levels of IgG were lower in the group that received $2000 \mathrm{mg} / \mathrm{kg}(p<0.05)$ than those of the control group.
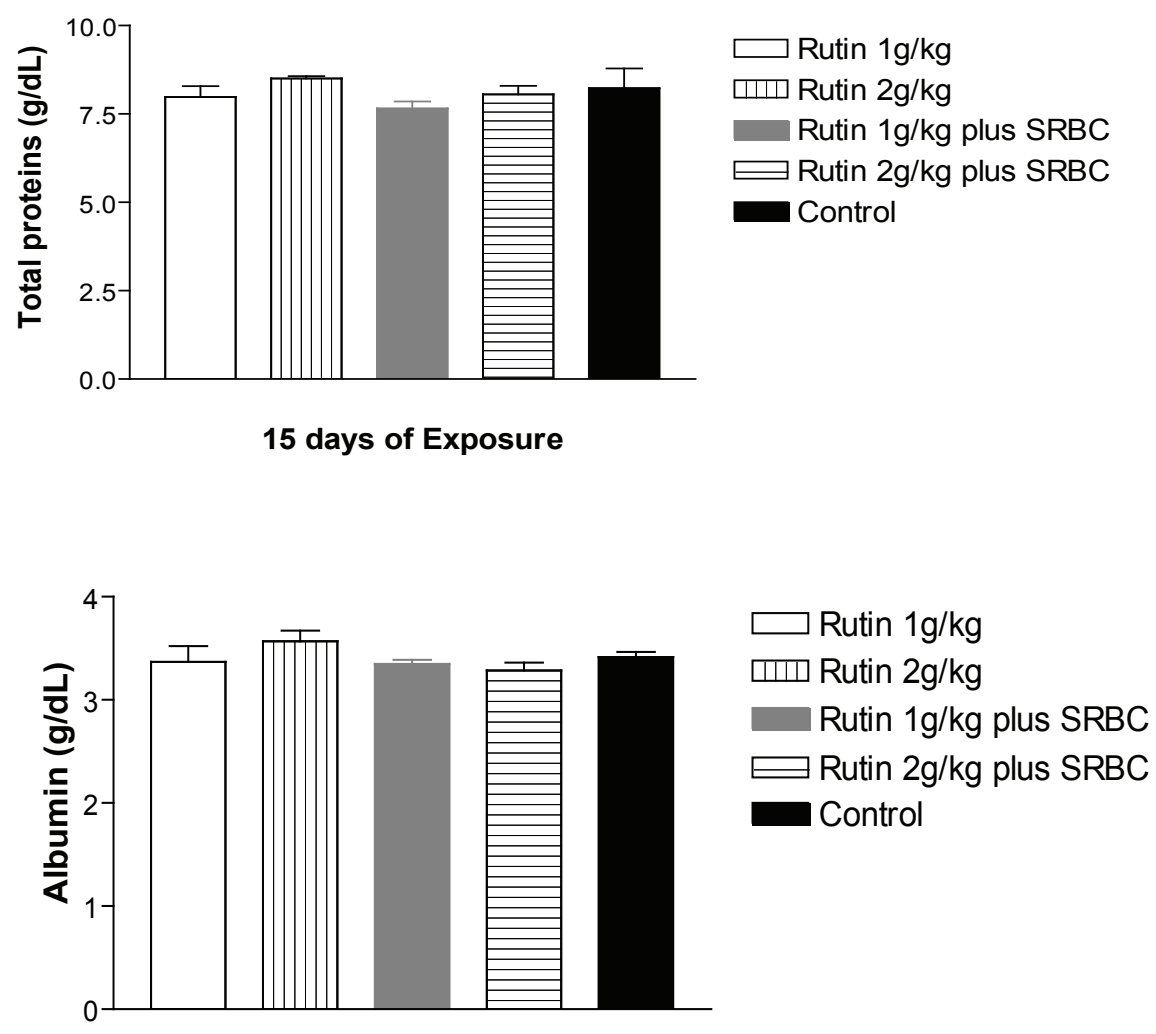

15 days of Exposure

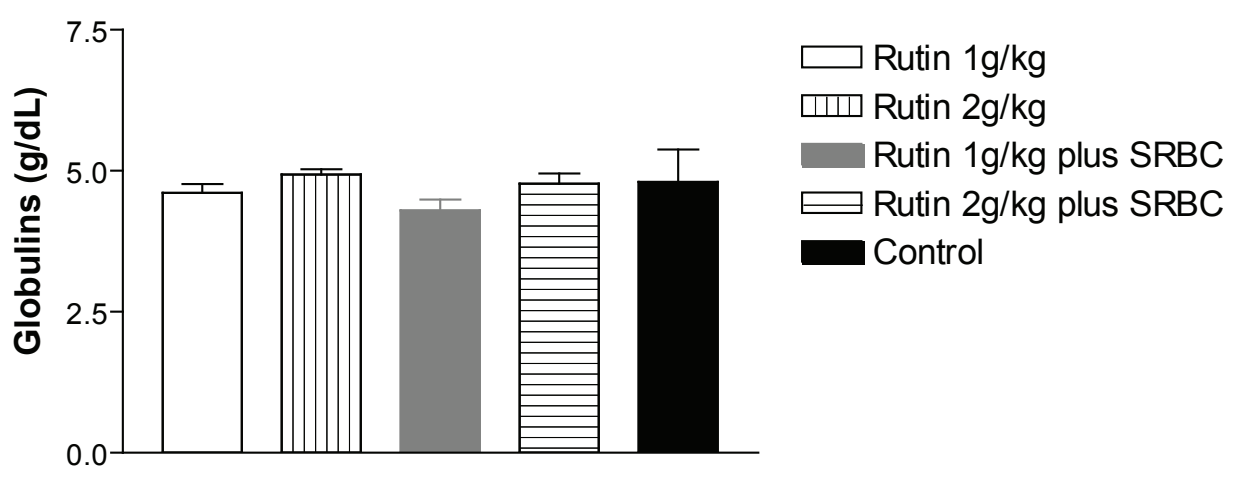

\section{0 days of Exposure}

Figure 1. Evaluation of the serum proteins: Total proteins (1.a), Albumin (1.b), globulin (1.c), after treatment for thirty days with a control suspension of carboxymethylcellulose (CMC) and with $1000 \mathrm{mg} / \mathrm{kg}$ and $2000 \mathrm{mg} / \mathrm{kg}$ doses of the semi-purified dried extract from Dimorphandra mollis Benth., Fabaceae (DMDE), with and without the association with sheep red blood cells (SRBC). 


\section{Lymphproliferative response}

No significant difference $(p<0.05)$ in the cells of rats that received $1000 \mathrm{mg} / \mathrm{kg}$ and $2000 \mathrm{mg} / \mathrm{kg}$ doses for 30 days relative to the control group composed of untreated animas was observed upon stimulation with Con A (Figure 4).
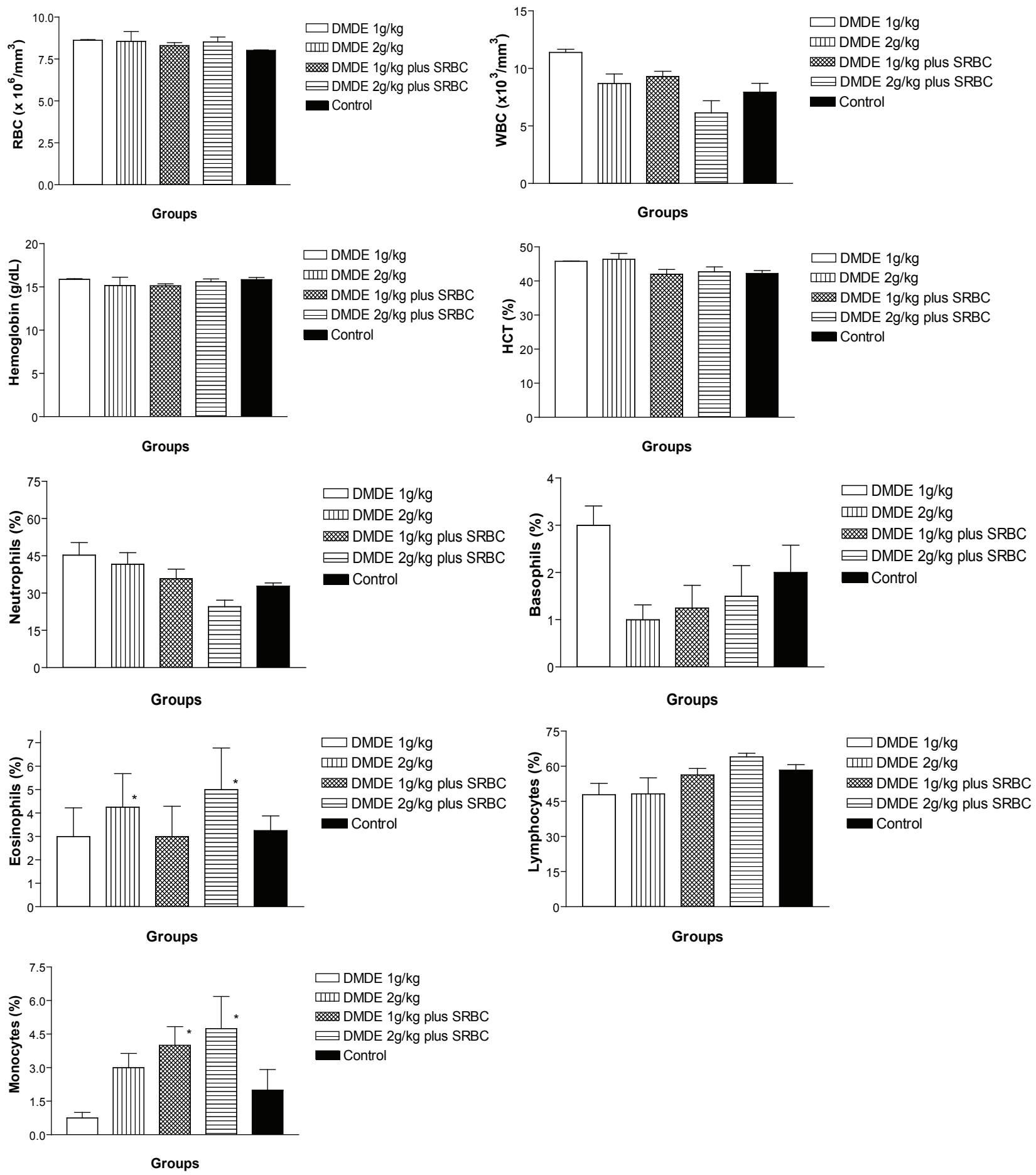

Figure 2. Hematological evaluation: Red blood cells (RBC) (2.a), White blood cells (WBC) (2.b), Hemoglobin (2.c), Hematocrit (HCT) (2.d) and Differential leukocyte (neutrophils-2.e, bastons-2.f, eosinophils-2.g, lymphocytes-2.h and monocytes-2.i) after treatment for thirty days with a control suspension (carboxymethylcellulose -CMC) and with $1000 \mathrm{mg} / \mathrm{kg}$ and $2000 \mathrm{mg} /$ $\mathrm{kg}$ doses of dried extract from Dimorphandra mollis Benth., Fabaceae (DMDE) with or without the association with SRBC; $\mathrm{n}$ $=5$; "values above the maximum value were considered to be within the minimum to maximum range of the reference values. 


\section{DISCUSSION}

The possibility of the development of a pathological condition such as immunostimulation, hypersensibility and immunosupression that can lead to an increase in the susceptibility for the development of tumors and infections is very important, especially in post-transplant patients that received prolonged immunosuppressive therapy (Herzyk \& Gore, 2004). The evaluation of different branches of immune response that permit the precise identification of some of these pathological conditions during the administration of an experimental drug is equally important. Some effects induced by drugs can lead to an alteration in the processing and in the presentation of antigens in the synthesis and the functioning of interleukin, in addition to cell differentiation and proliferation (Luster et al., 1992). The European guidelines recommended for immunotoxicology studies with repeated doses in rodents are regulated by the OECD 474 (28 days), and the studies must be conducted with the dose limit of 2000 $\mathrm{mg} / \mathrm{kg}$ (Alvarez et al., 2004). This immunotoxicological study of $D$. mollis was conducted with doses of 1000 and $2000 \mathrm{mg} / \mathrm{kg}$ for thirty days. The doses used in this study were obtained from LD50 test results (Féres et al, 2006). It is known that a yield of $76.0 \pm 3 \%$ of rutin is obtained from the DMDE obtained from $D$. mollis fruits (Féres et al, 2006). The fruits of this species represent an important therapeutic source, especially as a venous tonic and antioxidant, providing an alternative for the prevention and treatment of circulatory problems. A pre-clinical toxicity study demonstrated to be low for this extract (Féres et al, 2006). No alterations in the levels of total protein, albumin and globulin were observed in any of the groups evaluated (Figure 1). This fact indicates that there was probably no liver damage as a result of the administration of DMDE.

In the study of the hematological parameters (Figure 2), the values for red blood cells, hemoglobin, hematocrit and overall white blood cell count were observed to agree with those described by Jain (1986). These results suggest that a $1000 \mathrm{mg} / \mathrm{kg}$ dose of DMDE did not promote a change in the hematological parameters, but, when a dose of $2000 \mathrm{mg} / \mathrm{kg}$ was used, an increase in the number of eosinophils may suggest the occurrence of hypersensitivity. Although the indication of immunotoxicity may not have clinical relevance, it suggests that its use at this dosage or in repeated doses should be investigated further. The levels of antibodies were evaluated after the stimulation of the immune system with SRBC and the administration of DMDE for thirty days (Figure 3). Experiments on immunization of animals with a suspension of intact sheep red blood cells in a standardized concentration are widely described in the literature (Delaney et al., 2001; Ladics et al., 1995, Temple et al., 1993; Van Loveren et al., 1991), and some researchers have already used the suspension of industrialized SRBC (BioMérieux ${ }^{\circledR}$ ) (Alvarez et al., 2004).

No change in the levels of $\operatorname{IgG}$ in the group that received $1000 \mathrm{mg} / \mathrm{kg}$ of DMDE was observed, and, since this immunoglobulin is a marker for the chronic phase, this result has clinical significance. Therefore, the use of this phytotherapeutic drug at doses approximately twenty times greater than the usual therapeutic dose (15 to $100 \mathrm{mg} / \mathrm{kg}$ ) for a prolonged period did not alter the levels of specific IgG. However, a decrease in the levels of IgG, as compared to the control and $1000 \mathrm{mg} /$ $\mathrm{kg}$ group, was observed for the group that received $2000 \mathrm{mg} / \mathrm{kg}$ of DMDE.

Similar results of dose-dependent impaired humoral immune response were obtained by Alvarez et al. (2004), who observed that the humoral immune response decreased with the increase in dose when they assessed the immunotoxic potential of ochratoxina A (OTA) from a species of Aspergillus. The decrease in the levels of antibodies ( $\operatorname{IgG}$ ) observed in this study with the highest dose of DMDE is related to the results found in the histopathological evaluation of the spleen, in which hyperplasia of the white stroma was detected, a result that indicates that this organ reacts to the compound (data not shown).

In accord with the results presented for the lymphproliferative response (Figure 4), DMDE did not inhibit the lymphproliferative capacity mediated by the mitogen, thus maintaining the complete capacity for activation, differentiation and proliferation of spleen cells. These characteristics are vital to the effector viability of cell immunity. Therefore, DMDE presented no inhibitory activity on cellular immunity in this study.

In this context, it became necessary to evaluate, through standardized, safe methods, the potential for adverse effects to affect the dynamic and complex immune system. The evaluation of the immune response is indicated, mainly by the FDA (2002) and NTP (Luster et al, 1994), because of its higher predictive value for human toxicity (Olson et al., 2000). The possible immunotoxicological effects identified during the period of exposure to a particular drug are very important because they will be part of the assessment of its risk for use (Descotes, 2004; Olson et al., 2000).

No immunotoxicological study involving the D. mollis extract has been described in the literature. Studies with other plant species have been reported, such as Benencia et al. (2000), who identified dosedependent immunosuppressive activity in an extract from Trichilia glabra, which displays anti-viral, antiinflammatory and anti rheumatic properties. Sharma et al. (1994) detected an immunostimulatory potential in extracts from leaves of Picrorhiza kurroa, used for 
anti-inflammatory, anti-arthritis, gastrointestinal and urinary disorders. Tiwari et al. (2004) also detected immunostimulatory activity in an aqueous extract of Tridax procumbens (used for its anti-inflammatory, antimicrobial and hepatoprotectible properties).

The results showed that the DMDE did not interfere with the cellular response, but high doses, such as $2000 \mathrm{mg} / \mathrm{kg}$, a dose many times higher than the usual dose, can lead to an increase in the number of eosinophils, suggesting the occurrence of hypersensitivity, and can also cause a reduction in the levels of anti-SRBC antibodies. Therefore, considering the results of this work that showed no immunotoxic action for DMDE up to the dose of 1000 $\mathrm{mg} / \mathrm{kg}$, and possible modulation at higher doses such as $2000 \mathrm{mg} / \mathrm{kg}$, the continuation of immunotoxicological studies to ensure the safety and effectiveness of products produced with the flavonoid rutin is considered to be fundamental.

\section{Evaluation of chronic $\lg G$}

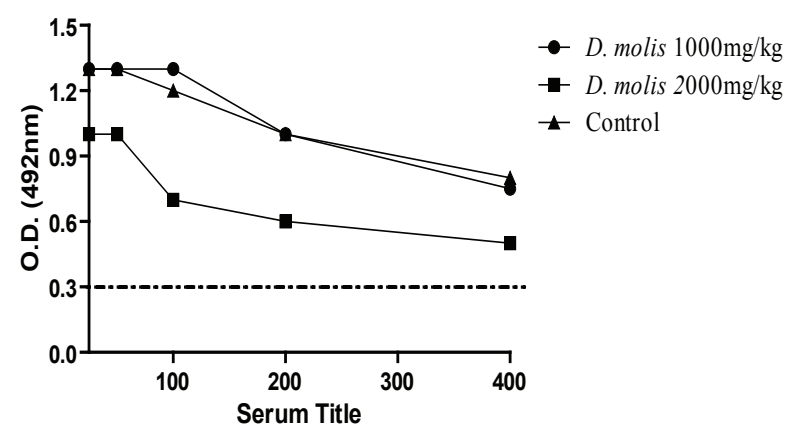

Figure 3. Immunoenzymatic determination of IgG anti SRBC. Mean absorbance at $492 \mathrm{~nm}$ obtained in the ELISA anti-IgG reaction performed with dilutions of the serum from the animals ( $\mathrm{n}=5$ per group) treated for thirty days with $1000 \mathrm{mg} / \mathrm{kg}$ and $2000 \mathrm{mg} / \mathrm{kg}$ doses of the semi-purified dried extract from Dimorphandra mollis Benth., Fabaceae (DMDE) and immunized with SRBC. Serum dilutions: $1=1: 25,2=1: 50,3=1: 100,4=1: 200$, $5=1: 400$. Duncan test, ${ }^{*}$ Significant difference $(p<0.05)$. - - - cut off

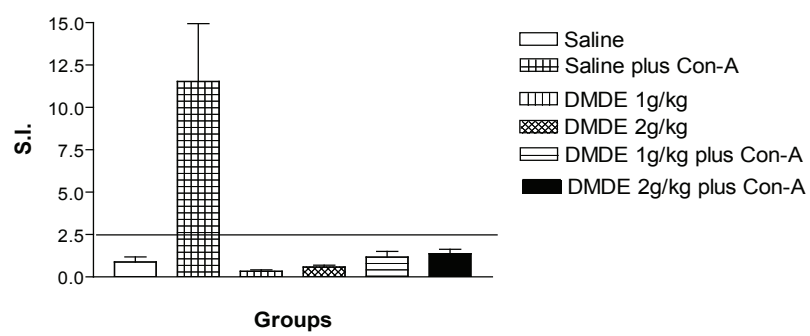

Figure 4. Lymphproliferative response of spleen cells induced by concanavalin $\mathrm{A}$. The vertical bar represents the arithmetic mean for each group. The spleen cells were stimulated with concanavalin A (mitogen) as a positive control for the lymphocyte proliferation tests. The horizontal bar represents the cut-off point. Kruskal-Wallis test for groups with concanavalin A $(p<0,05)$ and Duncan test for the remaining groups $(p<0,05)$. S.I. $=$ Stimulation index.

\section{REFERÊNCIAS}

Alvarez L, Gil AG, Ezpeleta O, Jalón-García JA, Cerain L 2004. Immunotoxic effects of ochratoxin A in Wistar rats after oral administration. Food Chem Toxicol 42: 825-834.

Arriba ML, Carvajal A, Pozo J, Rubio P 2002. Lymphproliferative responses and protection in conventional piglets inoculated orally with virulent or attenuated porcine epidemic diarrhoea virus. J Virol Methods 105: 37-47.

Bast T, Pezze MA, Feldon J 2002. Dopamine receptor blockade in the rat medial prefrontal cortex reduces spontaneous and amphetamine-induced activity and does not affect prepulse inhibition. Behav Pharmaco. 13: 669-73.

Da Silva J, Herrmann SM, Heuser V, Peres W, Marroni NP, González-Gallego J, Erdtmann B 2002. Evaluation of the genotoxic affect of rutin and quercetina by comet assay and micronucleus test. Food Chem Toxicol 40: 941-947.

Benencia F, Courrèges MC, Coulombié FC 2000. In vivo and in vitro immunomodulatory activities of Trichilia glabra aqueous leaf extracts. J Etnopharmacol 69: 199-205.

Delaney B, Philipis K, Buswell D, Mowry B, Nickels D, Cox D, Wang HB, Manthey J 2001. Immunotoxicity as a standartized citrus polymethoxylated flavone extract. Food Chem Toxicol 39: 1087-1094.

Descotes J 2000. Autoimmunity and toxicity testing. Toxicol Lett 113: 461-465.

Descotes J 2004. Importance of immunotoxicity in safety assessment: a medical toxicologist's perspective. Toxicol Lett 149: 103-108.

Erlund I, Kosonen T, Alfthan G, Maenpaa J, Perttunen K, Kenraali J, Parantainen J, Aro A 2000. Pharmacokinetics of quercetin from quercetin aglycone and rutin in healthy volunteers. Eur J Pharmacol 56: 545-553.

Féres CA, Madalosso RC, Rocha OA, Leite JP, Guimarães TMPD, Toledo VPCP, Tagliati CA 2006. Acute and chronic toxicological studies of Dimorphandra mollis in experimental animals. J Ethnopharmacol 108: 450-456.

Guardia T, Rotelli AE, Juarez AO, Pelzer LE 2001. Antiinflammatory properties of plant flavonoids. Effects of rutin, quercetin and hesperidin on adjuvant arthritis in rat. Farmaco 56: 683-687.

Hasumura M, Yasuhara K, Tamura T, Imai T, Mitsumori K Hirose M 2004. Evaluation of the toxicity of enzimatically decomposed rutin with 13-weeks dietary administration to Wistar rats. Food Chem Toxicol 42: 439-444.

Herzyk DJ, Gore ER 2004. Adequate immunotoxicity testing in drug development. Toxicol Lett 149: 115-122.

Holsapple MP, West LJ, Landreth KS 2003. Species comparison of anatomical and functional immune system development. Birth Defects Res B Dev Reprod Toxicol 68: 321-34.

Hou L, Zhou B, Yang L, Liu ZL 2004. Innibition of human low density lipoprotein oxidation by flavonols and their glycosides. Chem Phys Lipids 129: 209-219.

Jain NC 1986. Shalm's veterinary hematology. 4 ed. Philadelphia: Lea \& Febiger, $1221 \mathrm{p}$.

Janbaz KH, Saeed SA, Gilani AH 2002. Protetive effect of rutin on paracetamol- and $\mathrm{CCl}_{4}$-induced hepatotoxicity in rodents. Fitoterapia 73: 557-563.

La Casa C, Villegas I, Lastra AL, Motilva V, Calero MJM 2000. Evidence for protective and antioxidant properties of rutin, a natural flavone, against ethanol induced gastric lesions. J Ethnopharmacol 71: 45-53. 
Ladics GS, Smith C, Heaps K, Elliot GS, Slone TW, Loveless SE 1995. Possible incorporation of an immunotoxicological functional assay for assessing humoral immunity for hazard identification purposes in rats on standard toxicology study. Toxicology 96: 225-238.

Lowry OH, Rosebrough NJ, Farr AL, Randall RJ 1951. Protein measurement with the Folin phenol reagent. $J$ Biol Chem 193: 265-275.

Luster MI, Pait DG, Portier C, Rosenthal GJ, Germolec DR, Comment CE, Munson AE, White K, Pollock P 1992. Qualitative and quantitative experimental models to aid in risk assessment for immunotoxicology. Toxicol Lett 64: 71-78

Luster MI, Portier C, Pait DG, Germolec DR 1994. Use of animal studies in risk assessment for immunotoxicology. Toxicology 92: 229-243.

Nakamura Y, Ishimitsu S, Tonogai Y 2000. Effects of quercetin and rutin on serum and hepatic lipid concentrations, fecal steroid excretion and serum antioxidant properties. $J$ Health Sci 46: 229-240.

Nierkens S, Pieters R 2005. Murine models of drug hypersensitivity. Curr Opin Allergy Clin Immunol 5: 331-335.

Olson H, Betton G, Robinson D, Thomas K, Monro A, Kolaja G, Lilly P, Sanders J, Sipes G, Bracken W, Dorato M, Deun KV, Smith P, Berger B, Heller A 2000. Concordance of toxicity of pharmaceuticals in humans and in animals. Regul. Toxicol Pharmacol 32: 56-67.

Peijie C, Hongwu L, Fengpeng X, Jie R, Jie Z 2003. Heavy load exercise induced dysfunction of immunity and neuroendocrine responses in rats. Life Sci 72: 22552262.

Schwedhel ME, Maas R, Troost R, Boger RH 2003. Clinical pharmacokinetics of antioxidants and their impact on systemic oxidative stress. Clin Pharmacokinet 42: 437459.

Sharma JN, Srivastava KC, Gan EK 1994. Suppressive effects of eugenol and ginger oil on arthritic rats. Pharmacology 49: 314-318.

Sheu JR, Hsiao G, Chou PH, Shen MY, Chou DS 2004 Mechanisms involved in the antiplatelet activity of rutin, a glycoside of the flavonol quercetin, in human platelets. J Agric Food Chem 52: 4414-4418.

Shimol K, Yoshizumi K, Kido T, Usul Y, Yumoto T 2003. Absorption and urinary excretion of quercetin, rutin, and $\alpha \mathrm{G}$-rutin, a water soluble flavonoid, in rat. J Agric Food Chem 51: 2785-2789.

Temple L, Kawabata TT, Munson AE, White KL Jr 1993. Comparison of ELISA and plaque-forming cell assays for measuring the humoral immune response to SRBC in rats and mice treated with benzo $[\alpha]$ pyrene or cyclophosphamide. Fund Appl Toxicol 21: 412-419.

Tiwari U, Rastogi B, Singh P, Saraf DK, Vyas SP 2004. Immunomodulatory effects of aqueous extract of Tridax procumbens in experimental animals. J Ethnopharmacol 92: 113-119.

Tulinska J, Sovcikova A, Liskova A, Kubova J, Horakova K 2000 Immunotoxicity of ethyl-4-isothiocyanatobutanoate in male Wistar rats. Toxicology 145: 217-225.

Van Loveren H, Verlaan AP, Vos JG 1991. An enzyme-linked immunosorbent assay of anti-sheep red blood cell antibodies of the classes $\mathrm{M}, \mathrm{G}$, and $\mathrm{A}$ in the rat. Int $J$ Immunopharmacol 13: 689-695.
WHO 2003. Regional Office for the Western Pacific. Research guidelines for evaluating the safety and efficacy of herbal medicines. Manila: WHO. 